\title{
Factors Affect Mobile Phone Brand Choices - Studying the Case of Jordan Universities Students
}

\author{
Muhammad Alshurideh $^{1}$, Abdallah Bataineh ${ }^{2}$, Barween Alkurdi ${ }^{3} \&$ Nedal Alasmr $^{4}$ \\ ${ }^{1}$ Marketing Department, The School of Business, The University of Jordan, Jordan \\ ${ }^{2}$ Marketing Department, Applied Science Private University, Jordan \\ ${ }^{3}$ Part time lecturer, Durham Business School, Durham University, UK \\ ${ }^{4}$ The University of Jordan; Arab Bank, Jordan \\ Correspondence: Muhammad Alshurideh, Head of Marketing Department, The School of Business, The \\ University of Jordan, Amman 11942, Jordan. Tel: 962-653-55000 ext. 24255. E-mail: m.alshurideh@ju.edu.jo
}

Received: November 20, 2014

Accepted: December 29, 2014

Online Published: February 25, 2015

doi:10.5539/ibr.v8n3p141

URL: http://dx.doi.org/10.5539/ibr.v8n3p141

\begin{abstract}
The aim of this research is to examine the main factors affect mobile phone brand choice from a behavioral perspective, through analyzing a set of pre-behavior and post-behavior factors from a Jordanian customer's perspective, the research adds value to the behavior analysis literature by expanding the scope of the Behavior Perspective Model (BPM) applications within a real behavior setting. Using a structured questionnaire consisted of a pre-tested set of questions, which were distributed to a hundreds of respondents in three main Jordanian universities. A Multinomial Logistic Regression analysis is used to investigate the predetermined factors that affect mobile phone brand choice as proposed by the BPM. Research results, conclusions, recommendations and future researches are also discussed.
\end{abstract}

Keywords: behavior setting, learning history, behavior consequences, brand choice, Jordan

\section{Introduction}

New information and communication technologies continue to penetrate countries in all regions of the world, as more and more people are getting connected. Countries are reaching a critical mass in terms of information and communication technologies (access and use), which accelerate information and communication technologies diffusion, moreover, boosting demand driven by the spread of mobile internet (Seo et al., 2008). Between 2010 and 2011, mobile cellular subscriptions registered double digit growth in developing countries markets, but an overall slowdown in comparison with previous years (Peters-Taxeira \& Badrie, 2012). They were prompted by the demand for better data transmission service; such as MMS (Multimedia Massage Service), email, and advance Web browsing (Sharples, 2000). Typically, the cell phone industry is technology oriented, and belonged to the push-driven market. Its product created ahead of recognition of consumer need, Karjaluoto et al. (2006). Cell phones greatly assist people in communication anytime, and anywhere in the world. Mobile phone brand choice is a crucial area of study nowadays. Previous studies have failed to provide a comprehensive theoretical framework justification, and explain the customer choice from behavioral perspective. Customer choice occurs in a situation where a customer influenced by a variety of pre behavior, and post behavior factors which need to be taken into consideration. Thus, there is need to apply a theoretical framework that given a full understanding of customer choice. In order to provide a complete understanding of how customer choice takes place, the behavior perspective model (BPM) investigate the factors effect customer choice in mobile phone sector .The (BPM) of purchasing; and consumption is a complementary explanatory framework that provides a satisfactory interpretation of consumer behavior, with respect to both setting and consequences' key variables in which the behavior occurs (Foxall, 1992; Soriano et al., 2002). The model explains consumer behavior with reference to pre-behavior factors; and post-behavior consequential learning contingencies to translate person-situation interaction relationships in different behavior contexts. This model will be valid enough to be used to analyze factors that affect mobile phone brand choice. This research tends to examine the effect of a set of pre-behavior and post-behavior factors on mobile brand choice. Pre-behavior factors includes, behavior setting, and learning history, while the post-behavior factors includes, utilitarian reinforcement, utilitarian punishment, informational reinforcement, and informational 
punishment.

\section{Literature Review}

\subsection{Behavior Setting}

The main concern of marketing management; and marketers is to investigate how consumers respond to various marketing actions (Xiao, 2007). Marketing management behavior represents the main consumer behavior stimuli that control and influence his or her behavior setting. In order to illustrate this, a series of marketing management activities have been designed and properly executed to communicate stimuli by using different methods, such as marketing mix elements. Some suppliers often customize their offerings, and marketing policies in order to offer value to customers; and gain a competitive advantage over their close rivals who also target the customer segments of customers (Teichert et al., 2008). Foxall (1993) illustrated that behavior setting consists of all physical, social, temporal, and regulatory components that facilitate or inhibit consumer choice, and movement, and signal what the consequences will be for a particular way of behavior. This research will discuss each element separately in depth.

\subsubsection{Physical Setting}

In order to improve quality and productivity; and build a system for easy service delivery, customers should be involved directly or indirectly in planning, designing, and testing service processes and related tools (Hirsch \& Glanz, 2006; Boyazis, 2007). Many studies have been carried out to investigate the effect of several mobile service elements on consumer choice, such as the effect of mobile service or product attributes on consumer choice (Mazzoni et al., 2007), mobile phone price, image, and functions (Lin et al., 2010), mobile payment service (Schierz et al., 2009), and mobile service attributes (Cassab, 2009). Horvath and Sajitos (2002); for example, studied the role of mobile design on the buyer decision process and consumer responses. The researchers explained that consumer's relationship with product form is dependent upon their personal characteristics, surrounding products, utilities, experience, enjoyment of use, and contribution to fulfillment of objects purpose. Thus, consumer stimuli should be designed based of defining consumer characteristics and satisfying their needs.

\subsubsection{Social Setting}

There are many sources of social pressure such as family, friends, salesperson, marketers, and any person attending a consumer choice situation (Foxall, 1999; Leek et al., 2000). Thus, social environment must be taken into consideration when studying consumer choice, and purchasing behavior, especially if a specific choice object has gained social admiration from others. One of the main atmospheric elements in the behavior situation is customer's personal and social interactions with any of service firm's personnel. Accordingly, employees knowledge, skills, training, experience, and appearance are critical issues, especially for firms that have a high level of direct interaction with customers (Conduit \& Mavondo, 2001; Wooten \& Prien, 2007). Some organizations usually find it difficult to hire first rate people and keep them trained, productive, and happily employees treat customers properly and behave in a friendly manner toward them (Bowers et al., 2007).

\subsubsection{Temporal Setting}

Temporal setting defined as any factors that related to time or duration in purchasing behavior, Alessio (1984). There are many issues attached to temporal environment which should be considered when mobile supplier or provider plan their service offering, such as mobile contract duration, the offer starting and ending time, mobile warranty duration, mobile shop working hours duration. Reinartz, and Kumar (2000) studied the profitability of lifelong customers in a non-contractual setting, they tested four different propositions: First, the exists of strong positive customer lifetime profitability; second, the costs of serving lifelong customers are lower; third, profits increase over time; fourth, lifelong customer pay higher prices. The core finding of this study is that lifelong customers are not necessarily profitable customer. Levels of customer involvement, behavior consumption differ over the time duration. Moreover, there are many benefits (e.g. revenue growth over time, cost saving over time, referral income, and price premiums) that can be obtained from existing customers which increased within duration. Fink et al. (2008) confirmed the idea that customer, and supplier duration is an important variable in explaining what drives a customer to repurchase from the same shop or supplier. The interaction duration is translated by the contract duration which represents the formal length; which suppliers should exploit to make users renew or repurchase their mobile or to still purchase from this shop or suppliers simultaneously. Therefore, both parties drive great benefit from analyzing the interactions temporal related dimensions to enhance customer choice performance. This idea is confirmed by (Alshurideh, 2010; cited Cannon \& Homburg, 2001), and Fink et al. (2008), who claimed that suppliers can enhance their performance by enhancing their customers commitment, 
and performance duration the mutual interaction duration.

\subsubsection{Regulatory Setting}

According to Li \& Xu (2004) regulatory setting defined as any regulation or condition related to mobile. The effects of mobile service regulation appear in many aspects: economy development, and growth, investment requirements and operation licensing, mobile carrier's completion regulation, network operations, and mobile technology regulations, compliance with local and international regulations, and cooperation to organize suppliers relationship, with other partners in the market ( $\mathrm{Li} \& \mathrm{Xu}, 2004$; Varoudakis \& Rossotto, 2004). Regulatory factors which affect suppliers behavior also influence, and control customers behavior, and consumption of mobile service because parts of the mobile sector regulations are prearranged to organize a mutual customer supplier relationship in many aspects, such as contract duration and service consumption charges. From a wider perspective, regulation provides many benefits for both parties include organizing the customer and supplier, providing new product or service, determining different types and levels of mobile services, cost, and price regulations, safety regulations and obligations, defining contracts renewal and termination conditions, defining benefits types, and qualities, and providing additional customer benefits such as lowering mobile service price (Sutherland, 2007; Cheng, 2009). Moreover, mobile regulations are designed to protect consumer's privacy, and mobile service content such as voice, personal, financial, and data materials when a customer uses a mobile phone for internet shopping service (Mackay \& Weidlich, 2007). Based on the above literature, the behavior setting effect can be translated as:

H1: There is statistically significant effect of behavior setting on mobile brand choice.

\subsection{Learning History}

There are many situations where a consumer choice behavior with the same provider based on the accumulated experience of direct or indirect interaction with the service firms employees, and offerings (Andreassen \& Lindestad, 1998). The accumulated experience is translated by some researchers as the consumer's attitude towards and satisfaction with the attitude objectives, seen as the output of mutual consequences (Zins, 2001). Attitude is built up based on the customer's direct or indirect experienced interactions; with the purchased object of products or services and suppliers (Bredahl, 2001). Thus, a consumer choice is signaled and takes place at the intersection of the learning history, and behavior setting effects when a number of apparently similar alternatives need to be evaluated (Foxall, 1999; Foxall, 2008). As a result, consumer experience play's a critical role in customer choice behavior, especially when a customer is satisfied with previous purchase incident and object (Wong \& Sohal, 2003; Alshurideh et al., 2012). Meyer and Schwager (2007) defined customer experience as "the internal and subjective response customers have to any direct or indirect contact with a company" (p. 118). Both authors mentioned that direct contact is usually initiated by customers, such as purchasing, using, choices, and consuming. Meanwhile, indirect contact represents the unplanned encounters with one of more of the company's representations (e.g. product, service, and brand); and takes the form of Word of Mouth. Accumulated information usually shapes consumer knowledge and affects his or her attitude positively or negatively toward the purchased object. If previous experience is available, it becomes the main credible source of information to provide some indicators of future behavior (Metzger et al., 2003). Thus, a consumer usually concentrates more on decision making process to collect additional information; that will help him or her evaluate different elements in purchasing situation (Espejel et al., 2009). Also, a consumer may sometimes have positive or negative attitude towards as specific brand or product or service without previous experience (Meyer, 2008). That comes as a result of the direct or indirect effect of different sources such as feedback from other or a formulated promotional mix effect. Based on the above literature, the learning history effect can be translated as:

H2: There is statistically significant effect of learning history on mobile brand choice.

\subsection{Behavior Consequences}

There are three types on contingent consequences in customer choice situation signaled by the behavior setting discriminative stimuli: utilitarian, informational reinforcement, and aversive consequences (Foxall, 1998). The aversive consequences have been divided by Foxall (2007) into utilitarian and informational punishment. The utilitarian reinforcement contains the tangible function or economic benefits; that stem from a consumer's decision to consume, while the informational reinforcement contains the intangible function that stems from others feedback (Foxall, 2005). It has been determined that reinforcement is the main distinct behavior outcome that increases the chance of specific behavior choice (Foxall, 2003).

\subsubsection{Utilitarian Reinforcement}

Little empirical research has been conducted to explore the customer choice benefits from the customer's 
perspective as part of studying customer choice behavior (Martin-Counsuegra et al., 2006). Utilitarian reinforcement is described as functional benefits gained from the purchasing, ownership, usage, and consumption of product or services (Leek et al., 2000). For example, increasing customer value, and delivering continuous benefits are considered part of the customer choice reinforcement that affects consumer's behavior and engages them in his or her brands or company. Kotler et al. (1999) suggested three ways in which a company can deliver more value than its competitors: charge a lower price, help a customer reduce his or her other cost, and add benefits, that make the offer more attractive. In the mobile phone sector, mobile suppliers provide a mix of products, and services to attract and satisfy different customer segments. Based on the above literature, the utilitarian reinforcement effect can be translated as:

H3: There is statistically significant effect of utilitarian reinforcement on mobile brand choice.

\subsubsection{Informational Reinforcement}

From an informational reinforcement (IR) perspective, many studies have highlighted the importance of indirect positive informational incentives and utilities; that a customer may receive during mobile phone product or service consumption or regarding brand choice, such as emotional attachments, admiration, and positive feedback received mainly from the social surroundings arising from the choices with different brands (Ilies et al., 2007). Foxall (2007) mentioned that informational reinforcement is symbolic, usually mediated by the responsive actions of others, and closely related to exchange value. It results from many dimensions; such as social statues and prestige, and arrives as feedback and recommendations from others. The informational reinforcement plays an essential role in customer choice behavior. To illustrate this element, there are many informational reinforcement that consumers are willing to gain, either from using mobile phone product, and services or from other social surroundings such as, family or suppliers employees regarding chose a specific brand. Such customer benefits are diverse: special treatment and care, establishing social bonds through conversational use of the mobile, improving social relationship, and interactions with others, feeling safe and secure, gaining pleasure and entertainment, enhanced confidence, admiration, social status, and expressing selfesteem (Cheok et al., 2004; Counts, 2007). Based on the above literature, the informational reinforcement effect can be translated as:

H4: There is statistically significant effect of informational reinforcement on mobile brand choice.

\subsubsection{Utilitarian Punishment}

One of the main behavior consequences of choice and purchasing of mobile offers; which has a combination of product or service is the "aversive outcome" or "punishment". Foxall (1998) placed aversive outcome into two main categories: utilitarian punishment, and informational punishment. Utilitarian punishment can be described as all tangible and direct or indirect negative functions of using and consuming mobile offers, such mobile cost. There are many types of aversive outcomes resulting from customer in choice mobile with one of shop or service firms. Gronroos (1992) differentiated between three types of cost: direct, indirect and psychological cost. Based on cost classification, it is easy to determine direct cost; which focuses on maintaining and terminating a customer choice like separate item, or total contract cost. However, determining the indirect cost is not an easy task; it has different facets, such as customer time, and effort spent searching and evaluating various mobile phone type, and suppliers and their related mobile offers (Lee et al., 2006).The reason behind switching behavior and the causes of the replace the mobile phone between different brands have been investigated by many researchers (Xavier \& Ypsilanti, 2008). Keaveney (1995), for example, identified eight cusses of switching behavior in service industries: core service failure's, price, inadequate employee responses to service failure, inconvenience, involuntary actors, ethical problems, competitive issues, and service encounter failures. The main punishment element that a supplier might face is losing its customers to rivals. In the mobile phone sector, the probability of switching is high in relation to other sectors (Seo et al., 2008). Based on the above literature, the utilitarian punishment effect can be translated as:

H5: There is statistically significant effect of utilitarian punishment on mobile brand choice.

\subsubsection{Informational Punishment}

Informational punishment, can be describe as all the intangible and direct or indirect negative functions of using and consuming mobile offers in the form of negative feedback, such as regret (Foxall, 2005). In order to understand consumer choice behavior, some researchers have discussed a number of choice concepts; that affect consumer behavior and supplier selection such as, feedback, risk, uncertainty, conflict, defection, complaints and poor protection of consumer's financial and personal data. These issues are considered among the main factors that affect mobile phone brand choice. The main source of informational punishment that affects a customer 
choice behavior is the risk of purchase behavior, especially if he or she has experienced negative consequences. Furthermore, Levelock et al. (1999) differentiated between seven types of perceived risk in choice and purchasing service: functional risk (unsatisfactory performance outcomes), financial risk (monetary loss and unexpected costs), temporal risk (wasting time and consequence of delays), and physical risk (personal injury or damage to possessions).Psychological risk (personal fear and emotions), social risk (how other think and react), and sensory risk (unwanted effects on any of the five senses). So, the more successful a customer is in determining any informational punishment related issue risk or negative feedback in first stage, the more he or she will minimize the level of punishment. Based on the above literature, the informational punishment effect can be translated as:

H6: There is statistically significant effect of informational punishment on mobile brand choice.

\section{Research Model}

This research aims to explore if there is any effect for a set of pre-behavior and post-behavior factors that should be taken into consideration at once within decision making process stage on mobile brand choice. The determinants factors are behavior setting, learning history, utilitarian reinforcement, utilitarian punishment, informational reinforcement, and informational punishment. Thus, according to the available literature, Figure (1) shows the interpretative BPM framework that summaries the main per-behavior and post-behavior drivers of mobile brand choice.

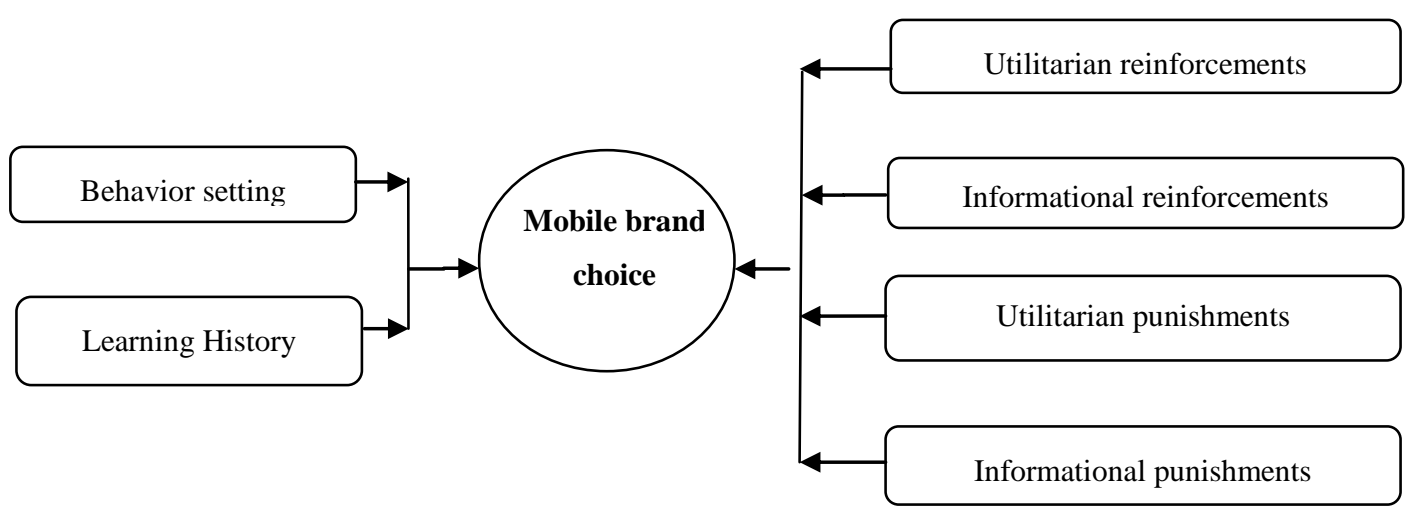

Figure 1. The Behavioral Perspective Model (BPM), adapted from Foxall (1998)

\section{Research Methodology}

\subsection{Data Collection Instrument}

The measurements of research variables were developed based on relevant literatures. The researchers started to collect secondary data from different sources e.g. books, articles, periodicals and so on in the late of 2012 till the med of 2013. A survey-questionnaire approach was used in the research. In order to analyses the collected data, the Multinomial Logistic regressions has been used, in knowing the effect of different independent variable on the dependent variable was conducted. All hypotheses were tested, and Beta coefficient was measured to see which independent variables influence most the dependent variable.

\subsection{Sample Size and Response Rate}

The response rate is considered one of the main survey elements of concern to researchers when they distribute questionnaires; it is a vital that they receive a suitable number of responses to fit the both sample size and analysis methods. Response rate consists of the number of completed and returned questionnaires divided by the total number of questionnaires sent out (Rada, 2005). It is an indicator of the confidence that may be derived as a result of legitimization of survey usage. Two different arguments have been attached on this rate. Some researchers have indicated that a low response rate can affect the reliability of any study (Edwards et al., 2002), while others argued that the response rate does not necessary increase the precision of the survey results (Dillman, 1991). The main goals achieved through calculating, and defining the response rate indicator in this study: it has helped in assessing the survey results accuracy and criticizing the self-reported questionnaire as a data collection instrument in investigating mutual relationship marketing. Table 1 demonstrates the four hundred and fifty questionnaires were distributed. The response rate in this study was $91.1 \%$, which is considered reasonably very good compared to other studies in the mobile phone sector. 
Table 1. Questionnaire response rate

\begin{tabular}{cccc}
\hline Response Rate & Questionnaire sent & Questionnaire returned & Questionnaire accepted for analysis \\
\hline $\mathbf{9 1 . 1 \%}$ & 450 & 425 & 410 \\
\hline
\end{tabular}

\subsection{Validity and Reliability}

The sample of this study is all users include students, because students are the largest group of people who use the mobile phone, and they have more experience than others in using the mobile phone. The researchers can reach the students easily since the researcher is also a student, and his age is close to their ages. The survey instrument was evaluated for validity. The items used in the questionnaire have been assessed, and tested by a panel of five arbitrators; who are experts in the field, they were selected from different Jordanian Universities whose knowledge and experience were sufficient in this scope, and thus their remarks and directions were taken into consideration. To provide evidence that the instrument produced the data for which it was designed, reliability test was conducted. As demonstrated in Table 2 the reliability values gained for all variables was greater than 0.65 indicating an acceptance of research testing, the reliability in the $70 \%$ range was acceptable and those who were over $80 \%$ were good (Sekaran, 2003).

Table 2. Reliability test for each variable

\begin{tabular}{cc}
\hline Variables & Cranach's Alpha \\
\hline All variables & $\mathbf{0 . 9 5 6}$ \\
Behavior setting construct & 0.876 \\
Physical setting & 0.702 \\
Social setting & 0.754 \\
Temporal setting & 0.667 \\
Regulatory setting & 0.792 \\
Learning history & 0.831 \\
Utilitarian reinforcement & 0.857 \\
Informational reinforcement & 0.826 \\
Utilitarian punishment & 0.818 \\
Informational punishment & 0.799 \\
Functional benefits & 0.854 \\
\hline
\end{tabular}

\section{Data Analysis}

\subsection{Demographic Analysis}

Table 3 illustrates that $58.3 \%$ of research sample are male, and $41.7 \%$ of them are female. The main purpose of this research, study the main factors affect mobile phone brand choice. However, it is good to mention the effect of gender in the mobile brand choice. Hung et al. (2003) found that young male users are more enthusiastic than female about adopting and using mobile. Regarding the sample age distribution, the majority of the samples respondents about $55.6 \%$ are between 18 and 25 years of total sample. This is the largest percentage of sample, because the young people are willing more than older people to buy and try new brand; and the application in the mobile had born to satisfy this segment of population. Regarding the study sample marital status, the sample respondents it has been found $60.5 \%$ are single and $33.4 \%$ are married. That is because the age of the largest sample age is between 18-25 years. Regarding the study sample education level, results show that $70.4 \%$ of the study participants are graduates who finished their university degree and about $14.4 \%$ completed the diploma studies ( 2 years), and $15.1 \%$ completed at least their school education. The present number means the most of sample respondents have sufficient knowledge to identify the enough data to choice their mobile brand from among a variety of alternatives. Seo et al. (2008), who studied demographic effects on customer choice behavior, found that both age and gender can affect customer choice behavior indirectly. In terms of the participant's monthly income level, $41 \%$ of the respondents, had an income of less than $400 \mathrm{JD}$. About $22.9 \%$ of the participant respondents had an income of between 400 and 599 JD. And around 36.2\% of them received more than 600 JD monthly. Different income level are demonstrated among the studied sample, which might produce 
more valuable results according the variety of mobile phone brand options which satisfy different customers need; these may differ from one income level to another.

Table 3. The respondent's demographics

\begin{tabular}{|c|c|c|c|}
\hline Variables & Category & Frequency & Percent \\
\hline \multirow[t]{3}{*}{ Gender } & Male & 239 & 58.3 \\
\hline & Female & 171 & 41.7 \\
\hline & Total & 410 & 100 \\
\hline \multirow[t]{5}{*}{ Age } & $18-25$ & 228 & 55.6 \\
\hline & $26-35$ & 109 & 26.6 \\
\hline & $36-45$ & 52 & 12.7 \\
\hline & above 45 year & 21 & 5.1 \\
\hline & Total & 410 & 100 \\
\hline \multirow[t]{5}{*}{ Marital Status } & Single & 248 & 60.5 \\
\hline & Married & 137 & 33.4 \\
\hline & Divorced & 14 & 3.4 \\
\hline & Widowed & 11 & 2.7 \\
\hline & Total & 410 & 100 \\
\hline \multirow[t]{5}{*}{ Education Level } & High school & 62 & 15.1 \\
\hline & Diploma (2 years) & 59 & 14.4 \\
\hline & Bachelor & 238 & 58 \\
\hline & Post-graduate & 51 & 12.4 \\
\hline & Total & 410 & 100 \\
\hline \multirow[t]{6}{*}{ Monthly Income } & Less than $400 \mathrm{JD}$ & 168 & 41 \\
\hline & 400-599 JD & 94 & 22.9 \\
\hline & 600-799 JD & 50 & 12.2 \\
\hline & 800-999 JD & 49 & 12 \\
\hline & $1000 \mathrm{JD}$ and above & 49 & 12 \\
\hline & Total & 410 & 100 \\
\hline
\end{tabular}

\subsection{Sample Distribution and Mobile Suppliers Segments}

Table 4 gives an idea of the numbers and percentages of study participants who subscribed to each of the main mobile phone suppliers in the Jordan market. There are three main mobile operators in Jordan: Zain, Umniah, and Orange. Results show that $60 \%$ of participants are subscribed to Zain, which gained the largest participant segment. Umniah was ranked second with $24.4 \%$, and Orange the last one $15.6 \%$ of the study sample respectively. Related to telecommunication regulatory commission of Jordan TRC, Zain company have the biggest market share, it constitute around $37.6 \%$ from the whole cellular market share, followed by Orange $35.4 \%$, then Umniah 26.2\% (TRC, 2013). The main reasons of why Zain has the largest percentage are, the network geographic coverage, and customer service support units distribute in all place. The price play main role to attract customer, based to that Zain has a good price regarding with other providers in the Jordan market.

Table 4. Cellular companies' providers

\begin{tabular}{ccc}
\hline Categories & Frequency & Percent \\
\hline Zain & 246 & 60.0 \\
Umniah & 100 & 24.4 \\
Orange & 64 & 15.6 \\
Total & $\mathbf{4 1 0}$ & $\mathbf{1 0 0}$ \\
\hline
\end{tabular}




\subsection{Mobile Phone Brands}

As seen in Table 5 shows that the largest number of participants using Samsung mobile with $33.2 \%$ of study sample, because Samsung mobile brand is fast, flexible, and fun operating system it has an explore smart phone accessories. And the second one is $31 \%$ for Nokia mobile because Nokia mobile is easy to use and it's including high volume. Apple mobile come in the next stage, it has $17.6 \%$ of study sample. Apple devices are recommended to Stanford users because of their security features regarding with other brands. Blackberry has 9.8\% of study sample, it's the first brand include a full keyboard and typing support with RIM's Sure Type technology. LG mobile has 3.9\%, Sony mobile has 3.4\% and Motorola mobile has the smallest percentage 1.2\% of study sample.

Table 5. Mobile phone brand

\begin{tabular}{ccc}
\hline Categories & Frequency & Percent \\
\hline Nokia Mobile & 127 & 31.0 \\
Apple Mobile & 72 & 17.6 \\
Samsung Mobile & 136 & 33.2 \\
Blackberry Mobile & 40 & 9.8 \\
LG Mobile & 16 & 3.9 \\
Sony Mobile & 14 & 3.4 \\
Motorola Mobile & 5 & 1.2 \\
Total & $\mathbf{4 1 0}$ & $\mathbf{1 0 0}$ \\
\hline
\end{tabular}

\subsection{Descriptive Analysis}

Five points likert scale has been used to distribute the respondents options when study items. The levels of the scale were given the following rating: (5) strongly agree, (4) agree, (3) neutral, (2) disagree, (1) strongly disagree. The standard mean of all statements equals $((5+4+3+2+1) / 5)=3$, the study considered the value below (3) is disagree and above that agree, the means and the standard deviations of different responses to the study factors as seen below in Table 6 .

Table 6. Descriptive analysis

\begin{tabular}{lccc}
\hline \multicolumn{1}{c}{ Study elements and factors } & Mean & Std. Dev. & Rank \\
\hline 1.The Behavior setting factor & 3.47 & 0.588 & $\mathbf{7}$ \\
1-A.The Physical setting factor & 3.27 & 0.739 & $\mathbf{7 - 4}$ \\
1-B. The Social setting factor & 3.56 & 0.712 & $\mathbf{7 - 2}$ \\
1-C. The Temporal setting factor & 3.48 & 0.779 & $\mathbf{7 - 3}$ \\
1-D. The Regulatory setting factor & 3.57 & 0.801 & $\mathbf{7 - 1}$ \\
2.The Learning history setting factor & 3.70 & 0.856 & $\mathbf{3}$ \\
3.The Utilitarian reinforcement factor & 3.76 & 0.798 & $\mathbf{2}$ \\
4.The Informational reinforcement factor & 3.55 & 0.832 & $\mathbf{5}$ \\
5.The Utilitarian punishment factor & 3.59 & 0.788 & $\mathbf{4}$ \\
6.The Informational punishment factor & 3.48 & 0.843 & $\mathbf{6}$ \\
7.The Functional benefits factor & 3.82 & 0.877 & $\mathbf{1}$ \\
\hline
\end{tabular}

Results in Table 6 shows that the participants view are on the average positively on all items. That's mean the participants agree positively with the behavior setting, learning history, utilitarian reinforcement, informational reinforcement, utilitarian punishment, informational punishment and functional benefits factor affect mobile phone brand choice.

\subsection{The Multinomial Logistic Regression}

To study customer brand choice behavior drivers, the relationship between multiple independent variables and categorical dependent variable were analyzed using Multinomial Logistic Regression demonstrated in Table 7. 
As confirmed by Fader et al. (1992), many researcher in marketing area have turned to the Multinomial Logistic Regression (MLR) technique in studying different behavioral and psychological phenomena, especially those involving multiple alternative such as brand choice behavior (Erdem et al., 2004). MLR is used in this research to analyses relationship between a non-metric independent variable and many dichotomous categories dependent variables.

Table 7. Hypotheses likelihood ratio test for customer choice behavior

\begin{tabular}{lcccc}
\hline Effect & Model Fitting Criteria & \multicolumn{3}{c}{ Likelihood Ratio Tests } \\
\cline { 2 - 5 } & -2 Log Likelihood of Reduced Model & Chi-Square & Df & Sig. \\
\hline Intercept & $843.872^{\mathrm{a}}$ & .000 & 0 &. \\
Behavior setting & $1820.709^{\mathrm{b}}$ & 976.837 & 348 & .000 \\
Learning history & $924.922^{\mathrm{b}}$ & 81.050 & 126 & .999 \\
Utilitarian reinforcement & $7506.635^{\mathrm{b}}$ & 6662.764 & 168 & .000 \\
Informational reinforcement & $6781.723^{\mathrm{b}}$ & 5937.852 & 156 & .000 \\
Utilitarian punishment & $927.408^{\mathrm{b}}$ & 83.536 & 132 & 1.000 \\
Informational punishment & $946.487^{\mathrm{b}}$ & 102.616 & 138 & .989 \\
Functional benefit & $943.646^{\mathrm{b}}$ & 99.775 & 108 & .702 \\
\hline
\end{tabular}

Scholars normally use probability measure at a significant level of 5\%. If P-value is less than the significant level, the results are considered statistically significant (e.g. p<0.05). Statistical results of customer brand choice effect are determined according to the statistical significant values of Chi-Square as show in table (3).

\section{Hypothesis Testing and Findings}

H1: There is statistically significant effect of behavior setting on mobile brand choice.

Table 7 shows the probability of the behavior setting Chi-Square statistic (977) is $\mathrm{p}=0.000$, below the level of significance of 0.05 . The hypo-research that expressed the relationship between the behavioral setting and customer choice has been accepted while there is statistically significant value that explains the relationship. The main concern of marketing management and marketers is to investigate how consumers respond to various marketing actions (Xiao, 2007). Marketing management behavior represents the main consumer behavior stimuli, which control and influence his or her behavior setting. In order to illustrate this, a series of marketing management activities have been designed and properly executed to communicate supplier's stimuli by using different methods such as, marketing mix elements. To communicate with reach a variety of customer targets, firms usually segment their customers and differentiate between them by offering different type of products, and service with different level of stimuli and incentive consequences. Some suppliers often customize their offerings; and marketing policies in order to offer value to customers and gain a competitive advantage over their close rivals who also target the customer segments of customers (Teichert et al., 2008).

H2: There is statistically significant effect of learning history on mobile brand choice.

Table 7 shows the probability of the mobile users learning history Chi-Square statistic (81) is $p=0.999$, more than the level of significance of 0.05 . The hypo-research that expressed the relationship between learning history, and customer choice is not supported as there is no statistically significant value that explain this. The reason for this result could be that the Jordanian customer willing to buy and try the new mobile device. So the back experience doesn't work in this factor.

H3: There is statistically significant effect of utilitarian reinforcement on mobile brand choice.

Table 7 shows the probability of utilitarian reinforcement Chi-Square statistic (6663) is $p=0.000$, less than the level of significance of 0.05 . The hypo-research that expressed the relationship between utilitarian reinforcement, and customer choice is supported as there is a statistically significant value that explains the relationship. Positive rewards are effect in the future choice. Some authors studied the process by which firms provide different type of reinforcement to intended customers to stimulate them to extend the mutual choice. For example, Alessio (1984) studied the continuous and intermittent reinforcement schedule. He hypothesized that intermittent reinforcement is better predictor of cohesiveness than continuous reinforcement. 
H4: There is statistically significant effect of informational reinforcement on mobile brand choice.

Table 7 shows the probability of informational reinforcement Chi-Square statistic (5938) is $\mathrm{p}=0.000$, less than the level of significance of 0.05 . The hypo-research that expressed the relationship between informational reinforcement and customer choice is supported as there is a statistically significant value that explains the relationship. The informational reinforcement plays an essential role in customer choice behavior. To illustrate this element, there is much informational reinforcement that consumers are willing to gain, either from using mobile phone product and services or from other social surroundings such as, family or suppliers employees regarding choose a specific brand. Such customer benefits are diverse: special treatment and care, establishing social bonds through conversational use of the mobile, improving social relationship, and interactions with others, feeling safe and secure, gaining pleasure and entertainment, enhanced confidence, admiration, social status, and expressing self-esteem (Leung \& Wei, 2000; Thang \& Tan, 2003; Cheok et al., 2004; Counts, 2007).

H5: There is statistically significant effect of utilitarian punishment on mobile brand choice.

Table 7 shows the probability of utilitarian punishment Chi-Square statistic (84) is $p=1$, more than the level of significance of 0.05 . The hypo-research that expressed the relationship between utilitarian punishment; and customer choice is not supported as there is no statistically significant value that explains the relationship. There are many types of aversive outcomes resulting from customer in choice mobile with one of shop or service firms. Gronroos (1992) differentiated between three types of cost: direct, indirect and psychological cost. Based on cost classification, it is easy to determine direct cost; which focuses on maintaining and terminating a customer choice like separate item, or total contract cost. However, determining the indirect cost is not an easy task; it has different facets, such as customer time and effort spent searching and evaluating various mobile phone type and suppliers and their related mobile offers (Lee et al., 2006). On the same theme, the psychological cost is also hard to determine and evaluate; it is described by Ravald and Gronroos (1996) as the cognitive effort needed to worry whether a supplier will fulfill his commitment or not. Therefore, utilitarian punishment does not show any effect on customer choice behavior. Rejecting this hypo-research in this way may be justified by two explanations: low-priced offers switching. And low priced items are not always a sufficient tool to attract new or existing customer.

\section{H6: There is statistically significant effect of informational punishment on mobile brand choice.}

Table 7 shows the probability of informational punishment Chi-Square statistic (103) is $p=0.702$, more than the level of significance of 0.05 . The hypo-research that expressed the relationship between informational punishment and customer choice is not supported, as there is no statistically significant value that explains the relationship. Firms are concerned about what consumers think of them and their products, especially when complaints of unpleasant experience occur (Clark et al., 1992) or dissatisfaction is felt (Bearden \& Teel, 1983). This is because there are many types on informational punishment harm that can befall both customers and firms directly or indirectly resulting from products or service choice, use and consumption, such as: negative customer feedback and unfavorable word of mouth. Informational punishment is described as indirect negative feedback that firms receive regarding their offering of products or services. Informational punishment, according to Oliveria-Castro et al. (2008), occurs when people don't approve of what consumer choice or purchased because they find it unpleasing. Therefore, informational punishment does not show any effect on customer choice behavior. Rejecting this hypo research in this way may be justified by the smaller the amount of negative consequences and disapproving feedback received from other individuals such as friends and family not used during purchasing or choose the mobile.

\section{Conclusion and Discussion}

The behavior setting elements are studied in this research by using quantitative methods. The findings show that the behavior setting elements is one of the main pre-behavior factors. As illustrated previously, the behavior setting was categorized into four elements according to the BPM: physical setting, social setting, temporal setting and regulatory setting. The results showed that regulatory and social setting is the main factors affecting mobile brand choice, and this result was consistent with the literatures e.g. (Conduit \& Mavondo, 2001; Wooten \& Prien, 2007; Sutherland, 2007; Cheng, 2009). The main studied element that were found to be critical for mobile brand choice behavior warranty condition and after sale service for the regulatory setting. The second behavior setting that influences mobile brand choice is the physical setting e.g. (Cassab, 2009). The main factors contributing to an explanation of mobile brand choice behavior are sales person explanation and friend opinions and recommendations. In addition, the temporal behavior setting factor is found to have influence on mobile brand choice (Fink et al., 2008). The main temporal element there found the mobile phone warranty duration important to stimuli the customer when introduce the mobile offer to the market. However, the study participants 
opinion indicated that the physical behavior setting was found have a positive influence on mobile brand choice. On the other hand, elements that were found to be critical for mobile brand choice behavior point of purchase promotion and the ability to offer customer online service. Each behavior setting elements plays a critical role in mobile brand choice behavior. Learning history factor is found to be one of the main pre-behavior factors (Espejel et al., 2009). Customers learning history has many elements, the main elements that were found essential for mobile brand choice behavior are as follows: first, positive experience with previous mobile make customer repurchases the same mobile brand; second, having a bad experience with previous mobile makes a customer's switch to others brands, this results were consistent with (Meyer, 2008). Moreover, if the customers have a positive experience the possibility of customer repurchase the same brand will be increased.

On the other hand, the utilitarian reinforcement factors are found to be the main customer's post-behavior factor that affects mobile brand choice. Quantitatively, the results show that the utilitarian reinforcement stimulates customer in choosing the mobile phone brand, the more positive consequences gained by customers through owning, using and consuming mobile phone brand, this result was consistent with (Leek et al., 2000). Regarding the indirect and intangible benefits received by consumers, informational reinforcement is also found to be one of the main determinants special mobile brands. The main informational reinforcement that was found to stimulate customers into purchase or choose a mobile is the positive hedonic values that are received through using mobile brand in terms of improving and enhancing the factors with others, in adding to allowing for social chatting. Positive feedback from others and feeling safe and secure add benefits in process of choosing a mobile phone brand, this results was consistent with (Ilies et al., 2007; Foxall, 2007). While consumer behavior is manipulated by its consequences, both utilitarian and informational punishment effects need to be highlighted. Quantitatively, it has been found that informational punishment influences mobile brand choices and behavior. However, no statistically significant value has been found that explains the effects of utilitarian punishment on mobile brand choice behavior, unlike the informational punishment. This means that a customer may switch mobile phone brand if the current brand reduce the amount of utilitarian punishment incurred through using a specific brand. There are many reason that contribute and effect in utilitarian punishment on choice a mobile brand: first, a consumer might change his/her current mobile if he/she had the negative feedback from other of the mobile brand. The results show that both utilitarian and informational punishment influence mobile brand choice negatively, this result was consistent with (Keaveney, 1995; Foxall, 2005). Consequently, the effect of behavior punishment is reduce, the possibility of choice behavior. Punishment reduction such as price reduction may affect the quality and value of the object (Zeithaml, 1988) or the seller image and brand name which in turn minimizes the chances of a specific behavior choice. In the mobile phone sector, there are many types of utilitarian punishment such as costs, switching cost, as well as any monetary value, and time and effort spent searching for mobile brand. Moreover, many informational punishment elements were studied, such as negative feedback from others, in addition to risk and fear from unfavorable outcomes that might occur from online mobile shopping.

\section{Recommendations and Future Research}

The research has added important value to the mobile brand choice behavior literature, especially within the individual level of mobile user behavior analysis. The analysis and illumination of mobile choice was one of the main contributions of this body of work, especially as it dealt with one of the most changeable businesses of the present era. However, many issues have been highlighted for future research. These issues presented themselves as research windows found during the literature review stage and also while conducting the empirical work. This research gives a preliminary opportunity to appraise the adoption of the BPM as a tool to provide a better understanding of mobile phone brand choice behavior. Through this, additional research venues are identified for investigation, such as, behavior setting, learning history, utilitarian reinforcement, informational reinforcement, utilitarian punishment, and informational punishment in the mobile phone sector. In addition, results obtained from this study denote that informational reinforcement is one of the main drivers that influence customer choice" behavior positively. However, by reviewing the customer behavior literature, it has been noted that informational reinforcement has not attracted much attention from scholars.

\section{References}

Alessio, J. C. (1984). Exchange, perceived alternatives, and reinforcement schedule: Cohesiveness among unmarried couples. Journal of Psychology, 118(1), 89-99. http://dx.doi.org/10.1080/00223980.1984.9712598

Alshurideh, M. (2010). A behavior perspective of mobile customer retention: An exploratory study in the UK Market. The End of the Pier? Competing perspectives on the challenges facing business and management British Academy of Management Brighton - UK. British Academy of Management, 1-19. 
Alshurideh, M., Nicholson, M., \& Xiao, S. (2012). The Effect of Previous Experience on Mobile Subscribers' Repeat Purchase Behaviour. European Journal of Social Sciences, 30(3), 366-376. Retrieved from http://scholar.google.com/citations?view_op=view_citation\&hl=ar\&user=7RX81y0AAAAJ\&citation_for_vi ew=7RX81y0AAAAJ:zYLM7Y9cAGgC

Andreassen, T. W., \& Lindestad, B. (1998). Customer loyalty and complex services. International Journal of Service Industry Management, 9(1), 7-23.

Baker, J. (1987). The role of the environment in marketing services: The consumer perspective. The Services Challenge: Integrating for Competitive Advantage, American Marketing Association, Chicago, 79-84.

Bearden, W. O., \& Teel, J. E. (1983). Selected determinants of consumer satisfaction and complaint reports. Journal of Marketing Research, 20(1), 21-28. http://dx.doi.org/10.2307/3151408

Bowers, M. R., \& Martin, C. L. (2007). Trading places redux: Employees as customers, customers as employees. Journal of Services Marketing, 21(2), 88-98. http://dx.doi.org/10.1108/08876040710737859

Boyazis, S. (2007). Building The Perfect Customer Experience. Customer Interaction Solutions, 26(1), 12-13.

Bredahl, L. (2001). Determinants of consumer attitudes and purchase intentions with regard to genetically modified food: Results of a cross-national survey. Journal of Consumer Policy, 24(1), 23-61.

Cannon, J. P., \& Homburg, C. (2001). Buyer-seller relationships and customer firm costs. Journal of Marketing, 65(1), 29-43.

Cassab, H. (2009). Investigating the dynamics of service attributes in multi-channel environments. Journal of Retailing and Consumer Services, 16(1), 25-30. http://dx.doi.org/10.1016/j.jretconser.2008.08.001

Cheng, R. (2009). Virgin mobile joins rivals in lowering prices. Wall Street Journal - Eastern Edition, 253(83), B5-B5.

Cheok, A. D., Goh, K. H, ... Xubo, Y. (2004). Human pacman: A mobile, wide-area entertainment system based on physical, social, and ubiquitous computing. Personal and Ubiquitous Computing, 8(2), 71-81. http://dx.doi.org/10.1007/s00779-004-0267-x

Clark, G. L., Kaminski, P. F., \& David, R. R. (1992). Consumer complaints: Advice on how companies should respond based on an empirical study. Journal of Consumer Marketing, 9(3), 5-14. http://dx.doi.org/10.1108/07363769210035189

Conduit, J., \& Mavondo, F. T. (2001). How critical is internal customer orientation to market orientation? Journal of Business Research, 51(1), 11-24. http://dx.doi.org/10.1016/S0148-2963(99)00044-2

Counts, S. (2007). Group-based mobile messaging in support of the social side of leisure. Computer Supported Cooperative Work (CSCW), 16(1), 75-97. http://dx.doi.org/10.1007/s10606-007-9040-9

Dillman, D. A. (1991). The design and administration of mail surveys. Annual Review of Sociology, 17(1), 225-249. http://dx.doi.org/10.1146/annurev.soc.17.1.225

Edwards, P., Roberts, I., ... Kwan, I. (2002). Increasing response rates to postal questionnaires: Systematic review. British Medical Journal, 324(7347), 1169-1178. http://dx.doi.org/10.1136/bmj.324.7347.1183

Engel, J., ... Blackwell, R. (1995). Consumer behaviour. USA: The Dryden Press.

Erdem, T., J. Swait, et al. (2004). Brand credibility, brand consideration, and choice. Journal of Consumer Research, 31(1), 191-198. http://dx.doi.org/10.1086/383434

Espejel, J., Fandos, C., \& Flavián, C. (2009). The influence of consumer involvement on quality signals perception. British Food Journal, 111(11), 1212-1236. http://dx.doi.org/10.1108/00070700911001040

Fader, P. S., Lattin, J. M., \& Little, J. D. C. (1992). Estimating nonlinear parameters in the multinomial log it model. Marketing Science, 11(4), 372-385. http://dx.doi.org/10.1287/mksc.11.4.372

Fagerstrøm, A. (2005). The behavioural perspective model: A proposed theoretical framework to understand and predict online consumer behaviour. Paper presented at the EMCIS 2005 annual conference, Cairo, Egypt, pp. $1-11$.

Fink, R. C., ... James, W. L. (2008). The effects of performance, environmental uncertainty and relational norms on customer commitments to suppliers over the duration of customer-supplier relationships. International Journal of Management and Decision Making, 9(6), 660-685. http://dx.doi.org/10.1504/IJMDM.2008.021220 
Foxall, G. (1993). Consumer behavioras an evolutionary process. European Journal of Marketing, 27(8), 46-57.

Foxall, G. (1999). The behavioural perspective model consensibility and consensuality. European Journal of Marketing, 33(5/6), 570-596. http://dx.doi.org/10.1108/03090569910262143

Foxall, G. (2008). Reward, emotion and consumer choice: From neuroeconomics to neurophilosophy. Journal of Consumer Behavior, 7(4-5), 368-396.

Foxall, G. R. (1992). The behavioral perspective model of purchase and consumption: From consumer theory to marketing practice. Journal of the Academy of Marketing Science, 20(2), 189-198. http://dx.doi.org/10.1007/BF02723458

Foxall, G. R. (1998). Intention versus context in consumer psychology. Journal of Marketing Management, 14(1-3), 29-62. http://dx.doi.org/10.1362/026725798784959327

Foxall, G. R. (2003). The behavior analysis of consumer choice: An introduction to the special issue. Journal of Economic Psychology, 24(5), 581-588. http://dx.doi.org/10.1016/S0167-4870(03)00002-3

Foxall, G. R. (2005). Understanding consumer choice. New York: Palgrave Macmillan. http://dx.doi.org/10.1057/9780230510029

Foxall, G. R. (2007). Explaining consumer choice: Coming to terms with intentionality. Behavioural Processes, 75(2), 129-145. http://dx.doi.org/10.1016/j.beproc.2007.02.015

Grönroos, C. (1992). Facing the challenge of service competition: The economies of service. In A. Ravald, \& Ch. Grönroos (Eds.), The value concept and relationship marketing. European Journal of Marketing, 30(2), 19-30.

Hirsch, M. S., \& Glanz, E. (2006). Tomorrow's world of recruitment. People Management, 12(10), 48-48.

Horvath \& Sajtos. (2002). How do mobile communicate? The role of product design in product related consumer response: The case of mobile telephone. Advanced in Consumer Research, 29, 237-238.

Hung, S. Y., Ku, C. Y., \& Chang, C. M. (2003). Critical factors of WAP services adoption: An empirical study. $\begin{array}{llll}\text { Electronic Commerce } & \text { Research applications, }\end{array}$ http://dx.doi.org/10.1016/S1567-4223(03)00008-5

Ilies, R., Pater, I. E. D., \& Tim, J. (2007). Differential affective reactions to negative and positive feedback, and the role of self-esteem. Journal of Managerial Psychology, 22(6), 590-609. http://dx.doi.org/10.1108/02683940710778459

Karjaluoto, H. (2006). An investigation of third generation (3G) mobile technologies and services. Contemporary Management Research, 2(2), 91-104.

Keaveney, S. M. (1995). Customer switching behavior in service industries: An exploratory study. Journal of Marketing, 59(2), 71-82. http://dx.doi.org/10.2307/1252074

Kotler, P., ... Armstrong, G. (1999). Principles of marketing. New Jersey: Prentice Hall Europe.

Lee, J., Kim, Y., Jeong-Dong, L., \& Yuri, P. (2006). Estimating the extent of potential competition in the Korean mobile telecommunications market: Switching costs and number portability. International Journal of Industrial Organization, 24(1), 107-124. http://dx.doi.org/10.1016/j.ijindorg.2005.07.003

Leek, S., Maddock, S., \& Foxall, G. (2000). Situational determinants of fish consumption. British Food Journal, 102(1), 18-39. http://dx.doi.org/10.1108/00070700010310614

Leung, L., \& Wei, R. (2000). More than just talk on the move: Uses and gratifications of the cellular phone. $\begin{array}{llll}\text { Journalism and Mass Communication } & \text { Quarterly, 77(2), 308-320. }\end{array}$ http://dx.doi.org/10.1177/107769900007700206

$\mathrm{Li}, \mathrm{W} ., \& \mathrm{Xu}, \mathrm{L} . \mathrm{C}$. (2004). The Impact of privatization and competition in the telecommunications sector around the world. The Journal of Law and Economics, 47, 395-430. http://dx.doi.org/10.1086/422984

Lin, C. L., ... Chen, C. W. (2010). Planning the development strategy for the mobilecommunication package based on consumers' choice preferences. Expert Systems with Applications, 37(7), 4749-4760.

Lovelock, C., ... Vandermerwe, S. (1999). Service marketing: A European perspective. England: Prentice Hall.

Mackay, M. M., \& Weidlich, O. (2007). Case study: Conducting a web-based survey of mobile content usage by Australian mobile phone customers. International Journal of Mobile Marketing, 2(1), 28-33.

Martin-Consuegra, D., ... Molina, A. (2006). The customers' perspective on relational benefits in banking 
activities. Journal of Financial Services Marketing, 10(4), 98-108.

Matheis, M. (2007). Personal relationships return customer insights. Marketing News, 41(8), 22-24.

Mazzoni, C., Castaldi, L., \& Addeo, F. (2007). Consumer behavior in the Italian mobile telecommunication market. Telecommunications Policy, 31(10-11), 632-647. http://dx.doi.org/10.1016/j.telpol.2007.07.009

McGovern, G., \& Moon, Y. (2007). Companies and the customers who hate them. Harvard Business Review, 85(6), 78-84.

Metzger, M. J., Flanagin, A. J., \& Zwarun, L. (2003). College student Web use, perceptions of information credibility, and verification behavior. Computers \& Education, 41(3), 271-290.

Meyer, C., \& Schwager, A. (2007). Understanding Customer Experience. Harvard Business Review, 85(2), 137-137.

Meyer, T. (2008). Experience-based aspects of shopping attitudes: The roles of norms and loyalty. Journal of Retailing and Consumer Services, 15(4), 324-333. http://dx.doi.org/10.1016/j.jretconser.2007.08.006

Oliveira-Castro, J. M., Foxall, G. R., ... Shing, W. C. (2008). Consumer-based brand equity and brand performance. The Service Industries Journal, 28(4), 445-461. http://dx.doi.org/10.1080/02642060801917554

Peters-Texeira, A., \& Badrie, N. (2012). Consumers' perception of food packaging in Trinidad, West Indies and its related impact on food choices. International Journal of Consumer Studies, 29(6), 508-514. http://dx.doi.org/10.1111/j.1470-6431.2005.00419.x

Rada, V. D. D. (2005). The effect of follow-up mailings on the response rate and response quality in mail surveys. Quality and Quantity, 39(1), 1-18. http://dx.doi.org/10.1007/s11135-004-5950-5

Ravald, A., \& Gronroos, C. (1996). The value concept and relationship marketing. European Journal of Marketing, 30(2), 19-30. http://dx.doi.org/10.1108/03090569610106626

Reinartz, W. J., \& Kumar, V. (2000). On the profitability of long-life customers in a noncontractual setting: An empirical investigation and implications for marketing. Journal of Marketing, 64(4), 17-35. http://dx.doi.org/10.1509/jmkg.64.4.17.18077

Schierz, P. G., Schilke, O., \& Wirtz, B. W. (2009). Understanding consumer acceptance of mobile payment services: An empirical analysis. Electronic Commerce Research and Applications, 9(3), 1-8. http://dx.doi.org/10.1016/j.elerap.2009.07.005

Sekaran, U. (2003). Research methods for business: A skill building approach. USA: John Wiley \& sons, Inc.

Seo, D., Ranganathan, C., \& Yair, B. (2008). Two-level model of customer retention in the US mobile telecommunications service market. Telecommunications Policy, 32(3-4), 182-196. http://dx.doi.org/10.1016/j.telpol.2007.09.004

Sharples, M. (2000). The design of personal mobile technologies for lifelong learning. Computers \& Education, 34(3-4), 177-193. http://dx.doi.org/10.1016/S0360-1315(99)00044-5

Soriano, M. Y., Foxall, R. G., \& Gordon, J. P. (2002). Emotion and environment: A test of the behavioural perspective model in a Latin American context. Journal of Consumer Behavior, 2(2), 138-154. http://dx.doi.org/10.1002/cb.96

Su, B. C. (2003). Risk behavior of internet shopping: Comparison of college students versus non-student adults. (ACM 1-58113-788-5/03/09), pp. 181-186.

Sutherland, E. (2007). The regulation of the quality of service in mobile networks. Info., 9(6), 16-23. http://dx.doi.org/10.1108/14636690710827668

Teichert, T., Shehu, E., \& Wartburg, I. V. (2008). Customer segmentation revisited: The case of the airline industry. Transportation Research Part A: Policy and Practice, 42(1), 227-242. http://dx.doi.org/10.1016/j.tra.2007.08.003

Thang, D. C. L., \& Tan, B. L. B. (2003). Linking consumer perception to preference of retail stores: An empirical assessment of the multi-attributes of store image. Journal of Retailing and Consumer Services, 10(4), 193-200. http://dx.doi.org/10.1016/S0969-6989(02)00006-1

Varoudakis, A., \& Rossotto, C. M. (2004). Regulatory reform and performance intelecommunications: Unrealized potential in the MENA countries. Telecommunications Policy, 28(1), 59-78.

Wong, A., \& Sohal, A. (2003). A critical incident approach to the examination of customer relationship 
management in a retail chain: An exploratory study. Qualitative Market Research: An International Journal, 6(4), 248-262. http://dx.doi.org/10.1108/13522750310495337

Wooten, W., \& Prien, E. P. (2007). Synthesizing minimum qualifications using an occupational area job analysis questionnaire. Public Personnel Management, 36(3), 307-314.

Xavier, P., \& Ypsilanti, D. (2008). Switching costs and consumer behavior: implications for telecommunications regulation. Info., 10(4), 13-29. http://dx.doi.org/10.1108/14636690810887517

Xiao, S. H. (2007). Trick or treat? An examination of marketing relationships in a nondeceptive counterfeit market. Social Science Research Network, WP-107(May), 1-42. http://dx.doi.org/10.1080/01608061.2010.499032

Zhou, L., \& Hui, M. K. (2003). Symbolic value of foreign products in the People's Republic of China. Journal of International Marketing, 11(2), 36-58. http://dx.doi.org/10.1509/jimk.11.2.36.20163

Zins, A. H. (2001). Relative attitudes and commitment in customer loyalty models. International Journal of Service Industry Management, 12(3), 269-294. http://dx.doi.org/10.1108/EUM0000000005521

\section{Copyrights}

Copyright for this article is retained by the author(s), with first publication rights granted to the journal.

This is an open-access article distributed under the terms and conditions of the Creative Commons Attribution license (http://creativecommons.org/licenses/by/3.0/). 